\title{
Analysis of Air Pollution Data in India between 2015 and 2019
}

\section{Aerosol and Air Quality Research}

\section{OPEN ACCESS}

Received: August 18, 2021

Revised: November 7, 2021

Accepted: December 10, 2021

\section{${ }^{*}$ Corresponding Authors: \\ Disha Sharma \\ dishas@princeton.edu \\ Denise Mauzerall \\ mauzerall@princeton.edu}

\section{Publisher:}

Taiwan Association for Aerosol Research

ISSN: $1680-8584$ print

ISSN: 2071-1409 online

Copyright: The Author(s). This is an open access article distributed under the terms of the Creative Commons Attribution License (CC BY 4.0), which permits unrestricted use, distribution, and reproduction in any medium, provided the original author and source are cited.

\author{
Disha Sharma ${ }^{1^{*}}$, Denise Mauzerall ${ }^{1,2^{*}}$ \\ ${ }^{1}$ Center for Policy Research on Energy and Environment, School of Public and International \\ Affairs, Princeton University, Princeton, NJ 08544, USA \\ ${ }^{2}$ Department of Civil and Environmental Engineering, Princeton University, Princeton, NJ 08544, \\ USA
}

\section{ABSTRACT}

India suffers from among the worst air pollution in the world. In response, a large government effort to increase air quality monitoring is underway. We present the first comprehensive analysis of government air quality observations from 2015-2019 for $\mathrm{PM}_{10}, \mathrm{PM}_{2.5}, \mathrm{SO}_{2}, \mathrm{NO}_{2}$ and $\mathrm{O}_{3}$ from the Central Pollution Control Board (CPCB) Continuous Ambient Air Quality Monitoring (CAAQM) network and the manual National Air Quality Monitoring Program (NAMP), as well as $\mathrm{PM}_{2.5}$ from the US Air-Now network. We address inconsistencies and data gaps in datasets using a rigorous procedure to ensure data representativeness. We find particulate pollution dominates the pollution mix across India with virtually all sites in northern India (divided at $23.5^{\circ} \mathrm{N}$ ) exceeding the annual average $\mathrm{PM}_{10}$ and $\mathrm{PM}_{2.5}$ residential national ambient air quality standards (NAAQS) by $150 \%$ and $100 \%$ respectively, and in southern India exceeding the $\mathrm{PM}_{10}$ standard by $50 \%$ and the $\mathrm{PM}_{2.5}$ standard by $40 \%$. Annual average $\mathrm{SO}_{2}, \mathrm{NO}_{2}$ and $\mathrm{MDA} 8 \mathrm{O}_{3}$ generally meet the residential NAAQS across India. Northern India has ( 10\%-130\%) higher concentrations of all pollutants than southern India, with only $\mathrm{SO}_{2}$ having similar concentrations. Although inter-annual variability exists, we found no significant trend of these pollutants over the five-year period. In the five cities with Air-Now $\mathrm{PM}_{2.5}$ measurements - Delhi, Kolkata, Mumbai, Hyderabad and Chennai, there is reasonable agreement with $\mathrm{CPCB}$ data. The $\mathrm{PM}_{2.5}$ CPCB CAAQM data compares well with satellite derived annual surface $\mathrm{PM}_{2.5}$ concentrations (Hammer et al., 2020), with the exception of the western desert region prior to 2018 when surface measurements exceeded satellite retrievals. Our reanalyzed dataset is useful for evaluation of Indian air quality from satellite data, atmospheric models, and low-cost sensors. Our dataset also provides a baseline to evaluate the future success of National Clean Air Programme as well as aids in assessment of existing and future air pollution mitigation policies.

Keywords: Air pollution, India, surface observations, CPCB, continuous and manual data, US AirNow

\section{INTRODUCTION}

Concerns over poor air quality in India have increased over the past few years with increasing evidence of the adverse impacts on health (Balakrishnan et al., 2014; Chowdhury and Dey, 2016; Balakrishnan et al., 2019), agricultural yields (Avnery et al., 2011, 2013; Ghude et al., 2014; Gao et al., 2020) and the economy (Pandey et al., 2021). Rapid growth and industrialization in India have resulted in some of the most polluted air in the world. Projections forecast further decreases in air quality and a $24 \%$ increase in $\mathrm{PM}_{2.5}$ associated premature mortalities by 2050 relative to 2015 (GBD MAPS Working Group, 2018; Brauer et al., 2019). According to recent estimates based on the Global Exposure Mortality Model (GEMM), total premature mortality due to ambient $\mathrm{PM}_{2.5}$ exposure in India increased approximately 47\% between 2000 and 2015 (Chowdhury et al., 2020). Surface $\mathrm{O}_{3}$ concentrations are also likely to increase with growing industrial emissions and increasing temperatures due to climate change resulting in additional stress on agricultural 
yields and public health (Avnery et al., 2011; Silva et al., 2017).

India has a national ambient surface monitoring network that started in 1987 and has become more extensive over time with a substantial increase in the number and spatial extent of continuous and manual monitoring stations between 2015 and 2019. At present, the Central Pollution Control Board (CPCB), along with the State Pollution Control Boards (SPCBs), run the most extensive monitoring network in the country under the National Air Quality Monitoring Program (NAMP). As of 2019, NAMP cooperatively operated (with CPCB and SPCBs) over 750 manual monitoring stations (compared with 20 in 1987 when monitoring first began and 450 in 2015 when our analysis starts) which publicly archive annual average concentrations of $\mathrm{PM}_{10}, \mathrm{PM}_{2.5}, \mathrm{SO}_{2}$ and $\mathrm{NO}_{2}$ (https://cpcb.nic.in/namp-data/). As of 2019, over 220 Continuous Ambient Air Quality Monitoring (CAAQM) stations operated (compared with less than 50 stations in 2015 when our analysis starts). CPCB archives publicly available, real time data, every 15 minutes, from over 220 stations across India of an extensive list of criteria and non-criteria air pollutants and meteorological variables (https://app.cpcbccr.com/ccr/). Stations vary in the air pollutant species and meteorological data they collect. The manual monitors provide better spatial coverage than the continuous monitors but provide data on fewer air pollutants at much lower temporal resolution (annual average values versus every 15 minutes). However, both sets of monitoring stations sample exclusively urban areas despite the fact that rural areas have significant emissions from households and agricultural waste burning (Balakrishnan et al., 2014; Venkatraman et al., 2018). Pant et al. (2019) and the Supplementary Information (SI) (Section 1) describe other Indian monitoring networks which are less extensive and are not publicly available. India has fewer monitoring stations than most south and east Asian countries, with 1 monitor/6.8 million persons (Apte and Pant 2019; Brauer et al., 2019; Martin et al., 2019). Despite recent increases in urban monitoring stations across India, vast regions do not have monitors and except for satellite data for a few species, little information is available on surface concentrations of air pollutants in non-urban locations in India.

Recently, extreme levels of fine particulate air pollution in India, combined with a growing appreciation of the adverse impacts of elevated air pollution on health, led the Indian government to launch the National Clean Air Program (NCAP) in 2019 (Ministry of Environment, Forests and Climate Change NCAP, 2019). NCAP targets a reduction of $20-30 \%$ in $\mathrm{PM}_{10}$ and $\mathrm{PM}_{2.5}$ concentrations by 2024 relative to 2017 levels. One focus of NCAP is augmentation of the national monitoring network for which substantial financial support was announced in the 2020 Union Budget.

Despite a growing monitoring network and the need for analysis, prior to our work, no study holistically analyzed existing government surface air pollutant monitoring data across India. Most research studies analyzing ground monitoring data have focused on Delhi and the surrounding National Capital Region (NCR) (Guttikunda and Gurjar, 2012; Sahu and Kota, 2017; Sharma et al., 2018; Chowdhury et al., 2019; Guttikunda et al., 2019; Wang and Chen, 2019; Hama et al., 2020), and other major cities (Gurjar et al., 2016; Sreekanth et al., 2018, Yang et al., 2018; Chen et al., 2020). In addition, some studies also used ground observations to bias correct satellite measurements for India (Pande et al., 2018; Chowdhury et al., 2019; Navinya et al., 2020). However, a need remains for a comprehensive analysis of all surface data collected by manual NAMP and continuous CAAQM monitoring networks between 2015-2019 over which period monitoring increased substantially.

Here we provide the first national analysis of all available surface measurements of key criteria pollutants $\left(\mathrm{PM}_{10}, \mathrm{PM}_{2.5}, \mathrm{SO}_{2}, \mathrm{NO}_{2}\right.$ and $\mathrm{O}_{3}$ ) across India between 2015-2019. We use publicly available data from the NAMP manual and CAAQM real-time stations which have different spatial distributions and temporal resolutions. Collating spatio-temporal distributions of pollutant concentrations on inter-annual, annual, seasonal and monthly timescales, we present an overview of the variability in air pollution levels across the country and separately analyze pollution levels in northern (north of $23^{\circ} \mathrm{N}$ ) and southern India. We conduct case studies of five cities in India in which U.S. State Department $\mathrm{PM}_{2.5}$ monitors (Air-Now network) are present and, using additional data collected by CAAQM monitors, compare pollution status between these cities. We also compare analyzed annual average $\mathrm{PM}_{2.5}$ from the CAAQM network with the satellite derived surface $\mathrm{PM}_{2.5}$ (Hammer et al., 2020) and find good agreement between the two datasets. Our analysis will provide a valuable baseline to evaluate the future success of the NCAP in meeting its air pollution mitigation targets. 


\subsection{Criteria Pollutant Data}

We analyze all open-source data available from the manual (NAMP) and continuous (CAAQM) networks, as well as from the US Embassy and consulates Air-Now network from 2015-2019 for five criteria pollutants- $\mathrm{PM}_{10}, \mathrm{PM}_{2.5}, \mathrm{SO}_{2}, \mathrm{NO}_{2}$ and $\mathrm{O}_{3}$.

Datasets from 2015-2018 were acquired for NAMP and were acquired from 2015-2019 for CPCB-CAAQM and Air-Now networks directly from the following sources:

1) NAMP manual monitoring network (https://cpcb.nic.in/namp-data/): Annual average and annual maximum and minimum concentrations were obtained from a total of 730 manual stations. Higher resolution temporal measurements are not publicly reported by NAMP. We analyze data from 2015-2018 as datasets for 2019 were unavailable when our analysis was completed in December 2020.

2) CAAQM continuous monitoring network from the Central Control Room for Air Quality Management website (https://app.cpcbccr.com/ccr/): One-hour averages were calculated from reported 15 minute average concentrations. Neither the continuous nor manual monitoring stations include geolocations. To obtain the latitude/longitude coordinates of each station, we used the monitoring station name and geolocated them using Google maps.

3) U.S. State Department Air-Now network (https://www.airnow.gov/): One-hour average $\mathrm{PM}_{2.5}$ concentrations were obtained for monitors located in Delhi, Mumbai, Hyderabad, Kolkata and Chennai.

\subsection{Data Quality Control}

We directly utilize the data available from the NAMP and Air-Now networks, but process the data we use from the CAAQM network to ensure representative monthly, seasonal, and annual average air pollutant concentrations using the following method:

1. Missing data is removed. Values in excess of the reported range (see Table S1) are assumed to be errors and are removed. Values of 999.99 for $\mathrm{PM}_{10}$ and $\mathrm{PM}_{2.5}$ are retained as they may represent concentrations above the upper detection limit of the instrument. The U.S. Air-Now network data in New Delhi report 1-hour average $\mathrm{PM}_{2.5}$ concentrations between 1300 and $1486 \mu \mathrm{g} \mathrm{m}^{-3}$ during Diwali for each year. As CAAQM does not report values in excess of $999.99 \mu \mathrm{g} \mathrm{m}^{-3}$ for $\mathrm{PM}_{2.5}$ our annual means based on CAAQM will likely be biased low in some locations. In sequences of 24 or more consecutive identical hourly values, only the first value out of the sequence is retained. Data were processed following the QA/QC procedure described below. The percentage of data removed due to this processing is provided in Tables S2(a) and S2(b).

2. Diurnal mean values are calculated for criteria pollutants $\mathrm{PM}_{10}, \mathrm{PM}_{2.5}, \mathrm{SO}_{2}, \mathrm{NO}_{2}$ and $\mathrm{O}_{3}$ for each 12-hour day-night interval (between 6 am-6 pm and 6 pm-6 am (next day)), using a minimum of one hourly observation for each 12 -hour period. Daily means are calculated only for days that have a daytime or nighttime mean value. For $\mathrm{O}_{3}$, daily mean (MDA8) values are calculated as the maximum of 8-hour moving averages over a 24-hour period using at least 6 hourly observations. For all pollutants, monthly mean values are calculated for months that have at least 8 daily mean values (at least $25 \%$ of observations). To obtain annual average concentrations, we calculate quarterly means and require at least one monthly mean value as input to each quarterly mean concentration. At least two quarterly mean values are used for calculating annual average concentrations. This procedure is followed to ensure representativeness of data in diurnal, daily, monthly, seasonal, annual and interannual timeseries. Fig. 1 shows a flow chart describing the methodology for generating each step of the time-series.

\section{RESULTS}

\subsection{Strengths and Weaknesses of Available Air Quality Datasets}

Until the start of 2018 the Indian monitoring network had limited extent. Very few stations 
have operated continuously from 2015 to the present. The number of stations in the continuous monitoring network has increased dramatically since 2017 (Fig. 2) making it far more feasible now to evaluate air quality across India than in the past. However, spatial coverage is still limited

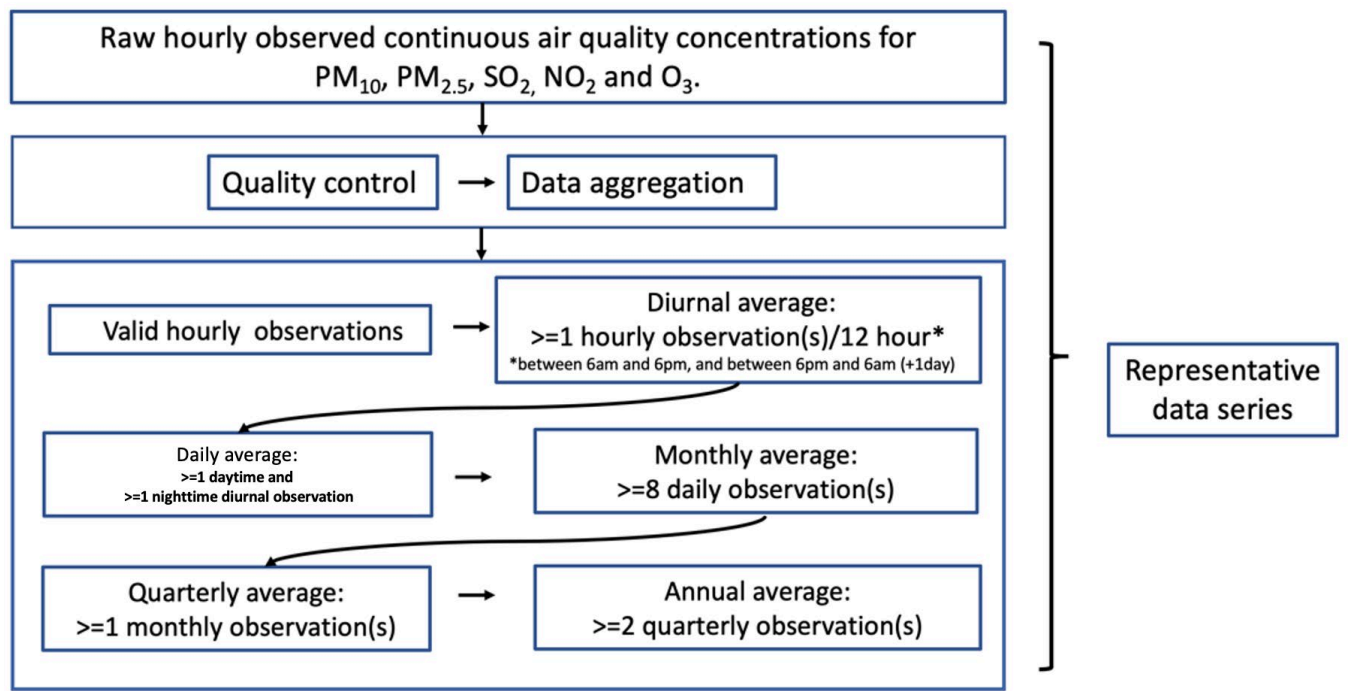

Fig. 1. Methodology used to create a representative data series for each pollutant which provides daily, monthly, seasonal and annual average concentrations.
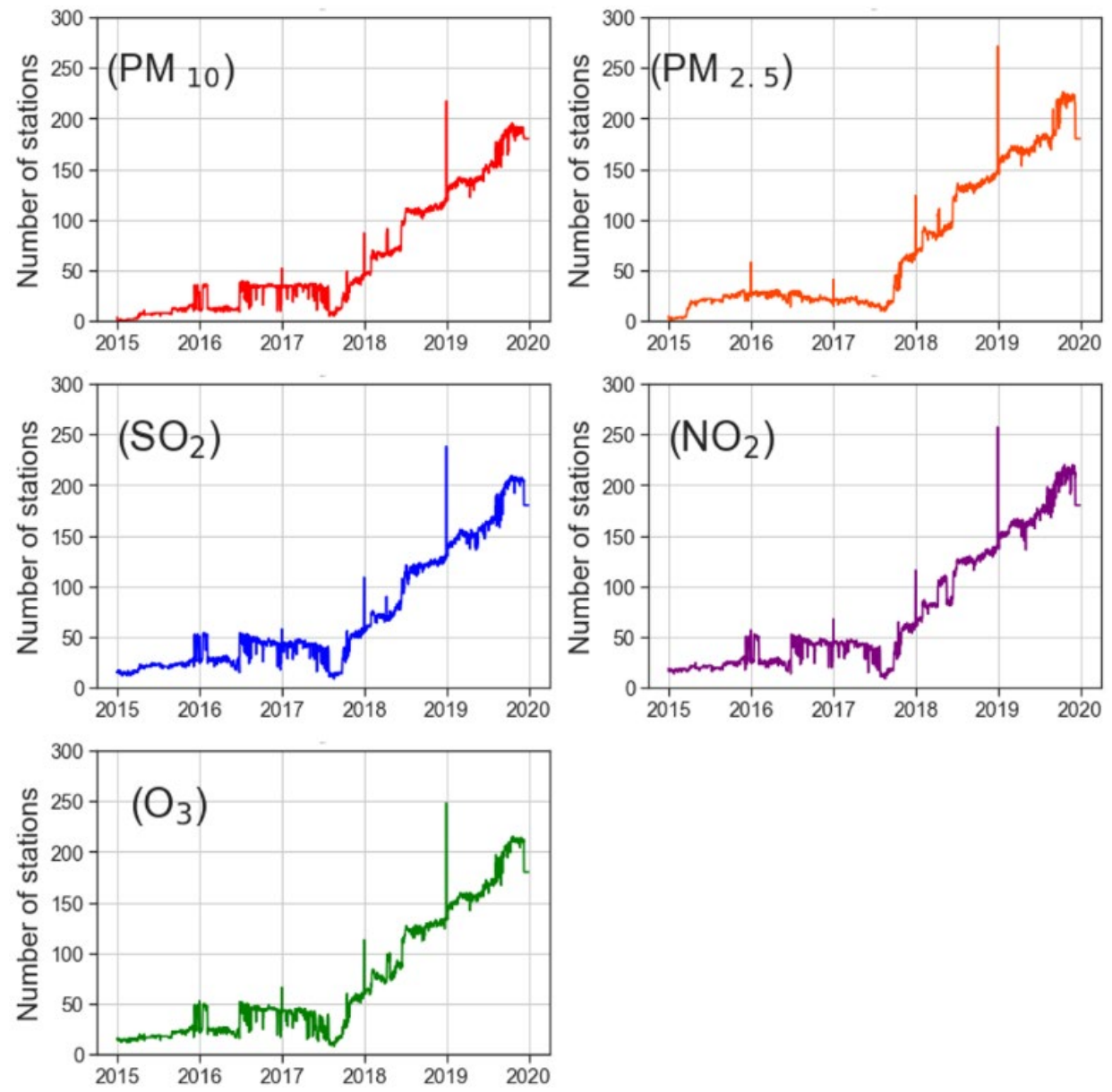

Fig. 2. Number of CAAQM stations providing valid hourly concentrations across India, between 2015-2019, for $\mathrm{PM}_{10}, \mathrm{PM}_{2.5}, \mathrm{SO}_{2}, \mathrm{NO}_{2}$ and $\mathrm{O}_{3}$, respectively. 


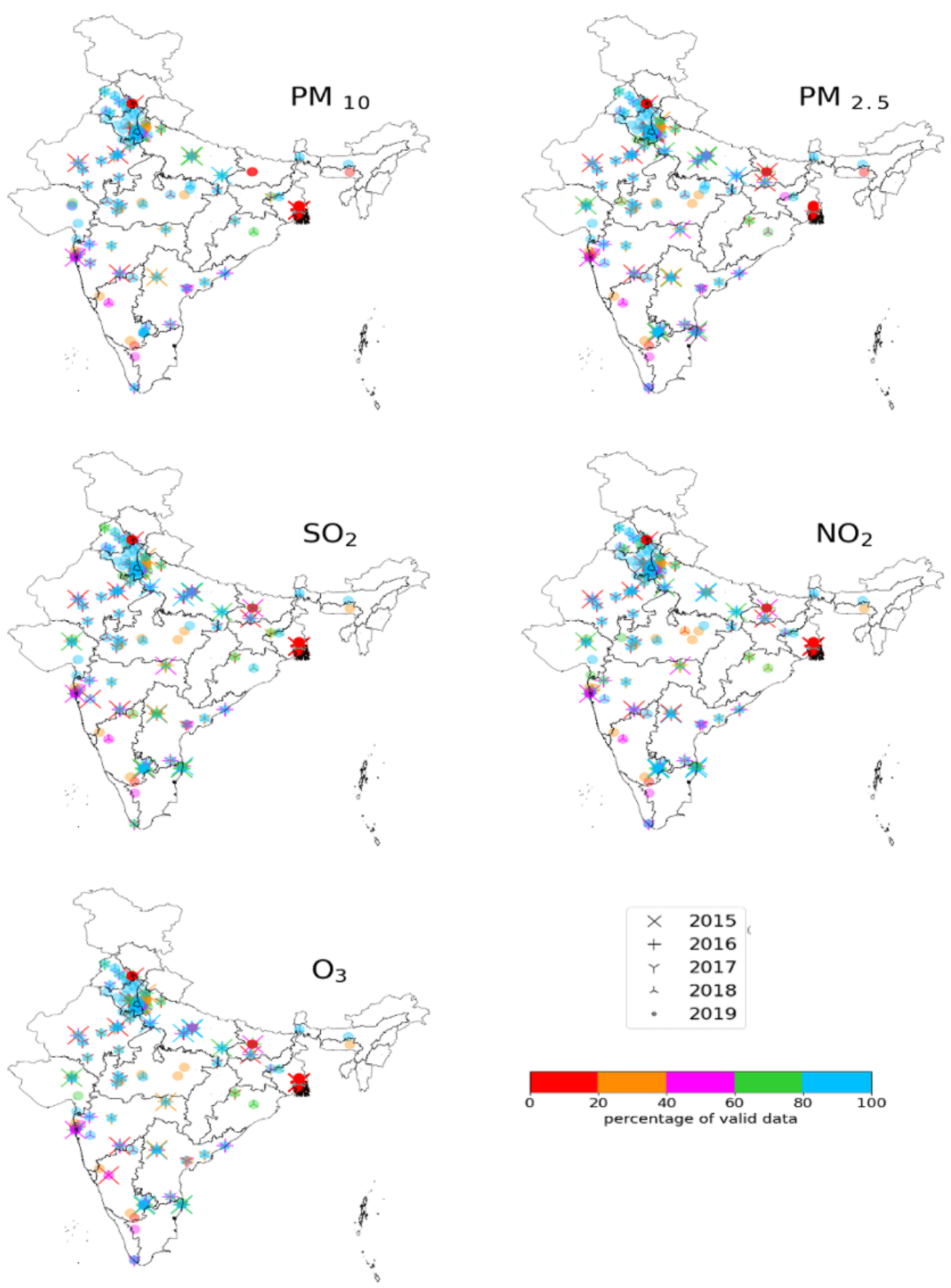

Fig. 3. Valid hourly CAAQM observations (as a percent of total hours) of $\mathrm{PM}_{10}, \mathrm{PM}_{2.5}, \mathrm{SO}_{2}, \mathrm{NO}_{2}$ and $\mathrm{O}_{3}$ at each station in a given year between 2015 and 2019.

with unequal distribution of monitors. All monitors are in cities, with a concentration in the largest cities, and none are in rural areas. Fig. 3 shows the percentage of valid hourly observations, compared with total hours annually, from each CAAQM station between 2015 and 2019. Although the current data is sufficient to provide an overview of air quality across much of India, it is currently challenging to use air quality datasets to conduct long term trend analysis due to their limited spatial and temporal coverage.

\subsection{Spatial Distribution of Air Pollutants from 2015-2019}

Figs. 4 and 5 show annual average concentrations of five criteria pollutants $\left(\mathrm{PM}_{10}, \mathrm{PM}_{2.5}, \mathrm{SO}_{2}\right.$, $\mathrm{NO}_{2}$ and $\mathrm{O}_{3}$ ) at continuous and manual monitoring stations across India, from 2015 to 2019. The 


\section{Annual Average Concentrations $\left(\mu \mathrm{g} / \mathrm{m}^{3}\right)$ - CAAQMS Continuous Monitoring Stations}

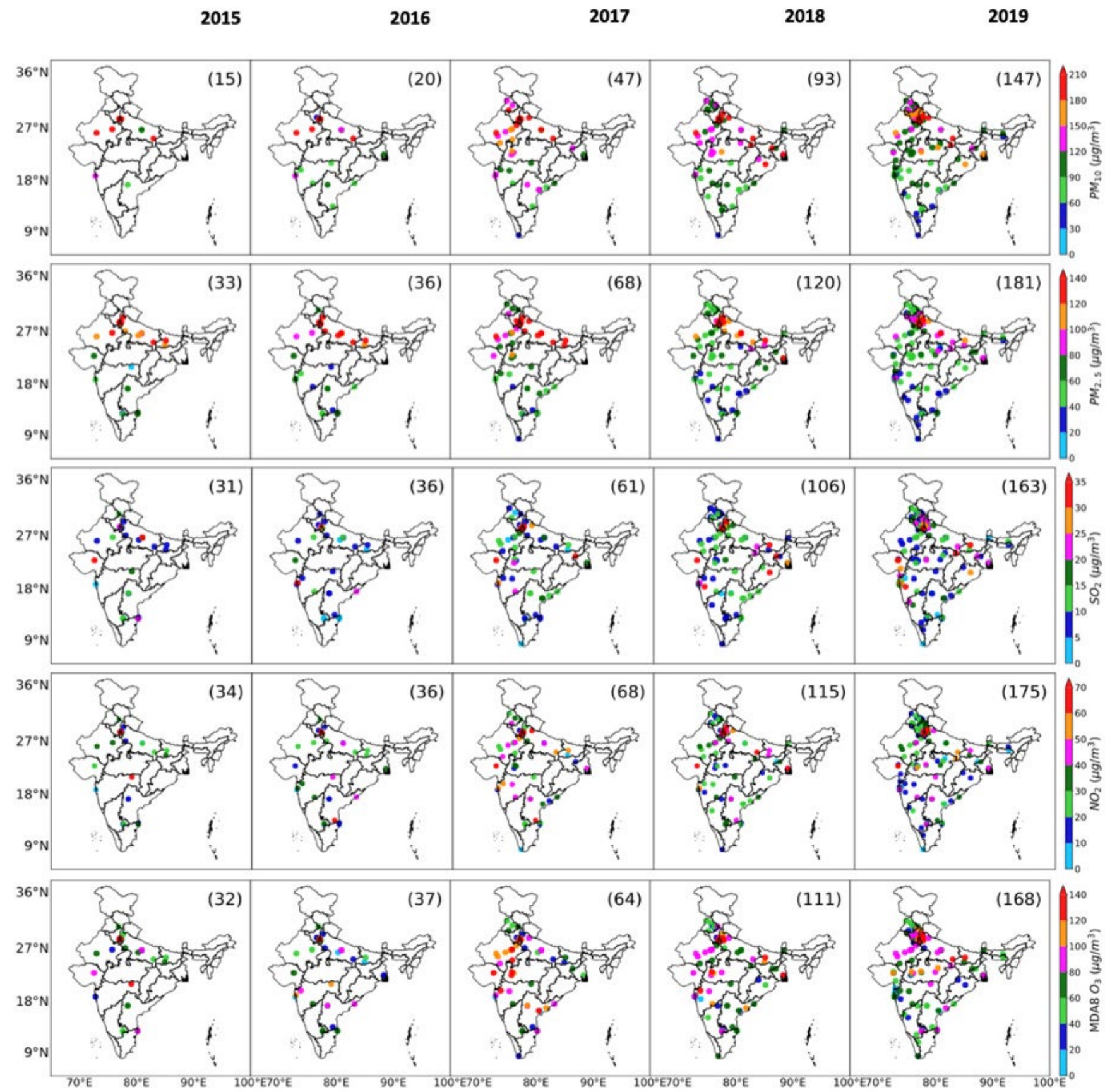

Fig. 4. Spatial distribution of annual average (2015-2019) concentrations ( $\mu \mathrm{g} \mathrm{m}^{-3}$ ) of $\mathrm{PM}_{10}, \mathrm{PM}_{2.5}, \mathrm{SO}_{2}, \mathrm{NO}_{2}$ and maximum daily average 8-hour (MDA8) $\mathrm{O}_{3}$ from the CPCB CAAQM continuous monitoring stations that meet our criteria for data inclusion (see methods for details). Each dot represents a single station. The number of stations for each species in each year is indicated in parentheses.

general distribution pattern of air pollution, showing higher pollution levels in northern than southern India, is captured in both the manual and continuous monitoring station data.

The number of continuous and manual monitoring stations have both increased substantially between 2015 and 2019 with 15 (147) CAAQM stations meeting our criteria for $\mathrm{PM}_{10}, 33$ (181) for $\mathrm{PM}_{2.5}, 31$ (163) for $\mathrm{SO}_{2}, 34$ (175) for $\mathrm{NO}_{2}$ and 32 (168) for $\mathrm{O}_{3}$ and in 2015 (2019) (see Figs. 4 and 5 for details of other years and manual stations). Of the total, nearly $60 \%$ of the CAAQM 


\section{Annual Average Concentrations $\left(\mu \mathrm{g} / \mathrm{m}^{3}\right)$ - NAMP Manual Monitoring Stations}

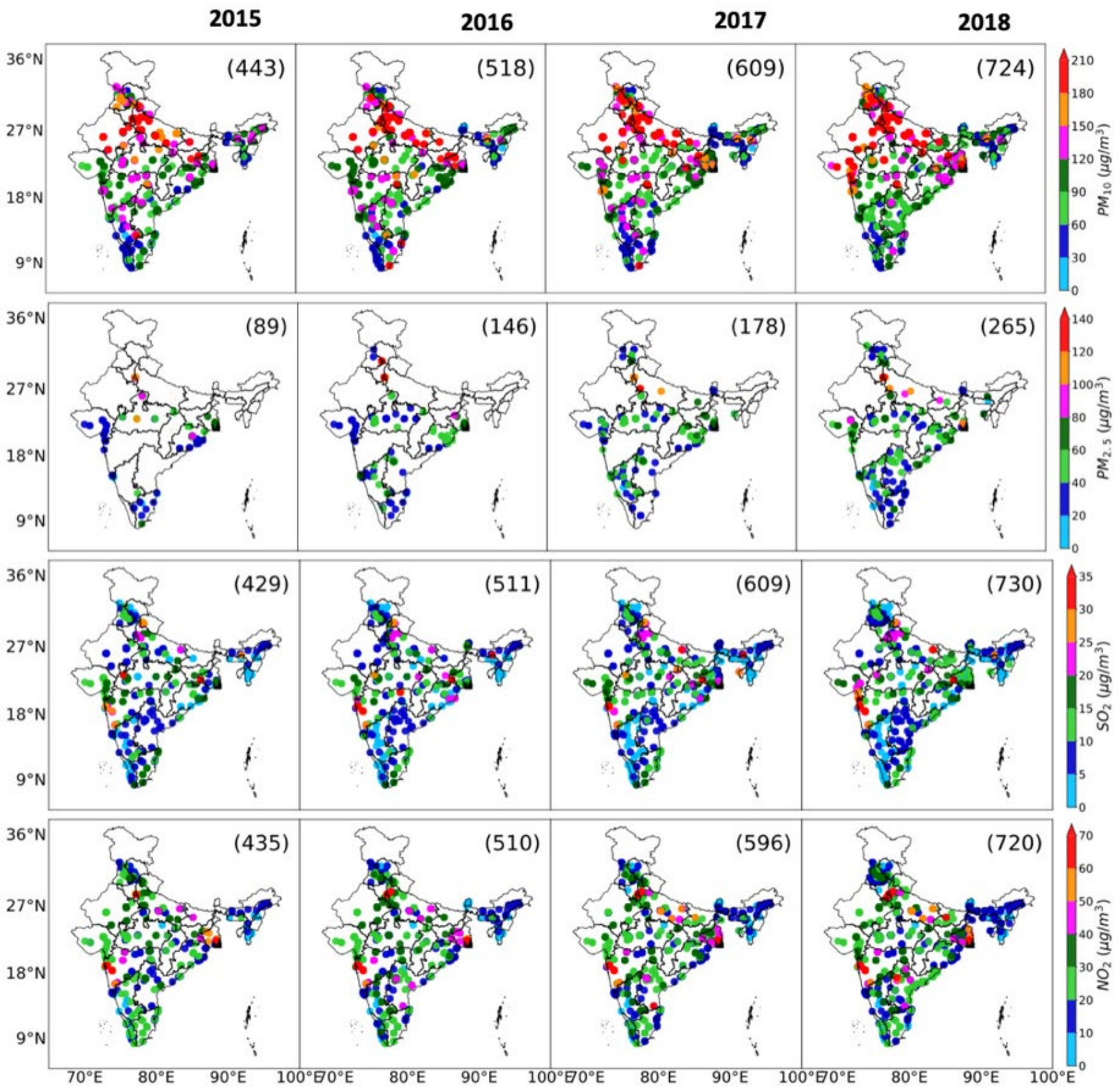

Fig. 5. Spatial distribution of reported annual average (2015-2018) concentrations $\left(\mu \mathrm{g} \mathrm{m}^{-3}\right)$ of $\mathrm{PM}_{10}, \mathrm{PM}_{2.5}, \mathrm{SO}_{2}$ and $\mathrm{NO}_{2}$ from NAMP manual stations (including all available observations). Each dot represents a single station. The number of stations in each year is indicated in parentheses.

continuous monitoring stations are in northern India with $20 \%$ of the total stations in Delhi in 2019. Despite being a high pollution zone with nearly $15 \%$ of the Indian population (http://up.gov.in/upstateglance.aspx), the Indo Gangetic Plain has only 13\% (9\%) of total continuous (manual) monitoring stations. NAMP manual monitoring stations are more widely distributed than continuous monitors across India, with more monitors in the south and thus provide more representative spatial distributions of pollutants. However, they only provide annual average pollutant concentrations and thus cannot be used to analyze seasonal variations. 
Elevated concentrations of $\mathrm{PM}_{10}$ and $\mathrm{PM}_{2.5}$ were recorded by both CAAQM and NAMP manual monitors across northern Indian states in all years, with particularly high concentrations across the Indo-Gangetic Plain (IGP). Ground observations of $\mathrm{SO}_{2}$ are generally low across the country with high concentrations found at a few urban and industrial locations. This has been corroborated by previous studies (Guttikunda and Calori, 2013). The role of alkaline dust in scavenging $\mathrm{SO}_{2}$ in India likely reduces ambient concentrations (Kulshrestha et al., 2003). In contrast, annual average $\mathrm{NO}_{2}$ and $\mathrm{MDA} 8 \mathrm{O}_{3}$ concentrations are highly variable depending on location with higher $\mathrm{O}_{3}$ concentrations often seen in the IGP region.

\subsection{Annual Variation in Pollutant Concentrations in Northern and Southern India}

The spatial distribution of pollutants is affected by meteorology, geography, topography, population density, location specific emission sources including industries, vehicular density, resuspended dust from poor land use management etc. In northern India (north of $23.5^{\circ} \mathrm{N}$ ), higher population density and higher associated activities in industry, transport, power generation, seasonal crop residue burning, and more frequent dust storms contribute to higher particulate loads than in southern India (Sharma and Dixit, 2016; Cusworth et al., 2018). We observed significant differences between northern and southern India in the spatio-temporal patterns of $\mathrm{PM}_{10}, \mathrm{PM}_{2.5}, \mathrm{SO}_{2}, \mathrm{NO}_{2}$ and MDA8 $\mathrm{O}_{3}$.

Fig. 6 shows annual average concentrations $\left(\mu \mathrm{g} \mathrm{m}^{-3}\right)$ of $\mathrm{PM}_{10}, \mathrm{PM}_{2.5}, \mathrm{SO}_{2}, \mathrm{NO}_{2}$ and $\mathrm{MDA} 8 \mathrm{O}_{3}$ respectively, for northern and southern India (divided at $23.5^{\circ} \mathrm{N}$ ) from CAAQM stations. The number of stations used to calculate annual average values is shown in Fig. 4 for each species. Annual average concentrations of $\mathrm{PM}_{10}, \mathrm{PM}_{2.5}$, and $\mathrm{NO}_{2}$ are higher in northern India, whereas $\mathrm{SO}_{2}$ and $\mathrm{MDA} \mathrm{O}_{3}$ are similar in the north and the south. Annual average concentrations from CAAQM continuous and NAMP manual monitoring stations, combined (S1 a), and only manual monitoring Stations (S1 b) are plotted separately in Fig. S1. We found inter-annual variability but no significant annual trend in the timeseries of these pollutants. Annual average concentrations over the five year period in northern (and southern) India were: $197 \pm 84 \mu \mathrm{g} \mathrm{m}^{-3}\left(93 \pm 30 \mu \mathrm{g} \mathrm{m}^{-3}\right.$ ) for $\mathrm{PM}_{10}, 109$ $\pm 29 \mu \mathrm{g} \mathrm{m}^{-3}\left(47 \pm 16 \mu \mathrm{g} \mathrm{m}^{-3}\right)$ for $\mathrm{PM}_{2.5}, 12 \pm 7 \mu \mathrm{g} \mathrm{m}^{-3}\left(12 \pm 10 \mu \mathrm{g} \mathrm{m}^{-3}\right) \mathrm{SO}_{2}, 35 \pm 21 \mu \mathrm{g} \mathrm{m}^{-3}(27 \pm$ $\left.16 \mu \mathrm{g} \mathrm{m}^{-3}\right)$ for $\mathrm{NO}_{2}$ and $73 \pm 29 \mu \mathrm{g} \mathrm{m}^{-3}\left(66 \pm 31 \mu \mathrm{g} \mathrm{m}^{-3}\right)$ for $\mathrm{MDA} 8 \mathrm{O}_{3}$. In the five-year period, annual NAAQS were met at approximately $3 \%$ of all CAAQM stations measuring $\mathrm{PM}_{10}, 13 \%$ of $\mathrm{PM}_{2.5}, 70 \%$ of $\mathrm{NO}_{2}$ and $98 \%$ of $\mathrm{SO}_{2}$ (Table S3). MDA8 $\mathrm{O}_{3}$ standard of $100 \mu \mathrm{g} \mathrm{m}^{-3}$ (to be met $98 \%$ of the time within a year) was met at 77\% of all CAAQM stations between 2015-2019, inclusive. Particulate matter dominates the pollution mix with national average annual mean concentrations exceeding the NAAQ standard for all analyzed years and in northern India more than double the allowed concentration. Fig. 7 shows annual average concentrations of these pollutants from CAAQM stations that meet our analysis criteria and are available each year from 2015 through 2019. The change in annual concentrations relative to the annual average concentrations in 2015-2017 at the stations operational throughout this period is shown in Fig. S2 in order to provide a comparison useful for evaluating the success of the NCAP.

\subsection{Seasonal and Monthly Patterns of Air Pollutants}

Seasonal concentrations of air pollutants in India are heavily influenced by meteorology and location. Influence of meteorology on spatio-temporal distributions of pollutants across India is described in Section S3. Fig. S3 shows the mean seasonal distribution of boundary layer height, surface pressure, precipitation, and omega/vertical and horizontal wind velocity. We calculate seasonal and monthly concentrations of $\mathrm{PM}_{10}, \mathrm{PM}_{2.5}, \mathrm{SO}_{2}, \mathrm{NO}_{2}$ and $\mathrm{MDA} 8 \mathrm{O}_{3}$ between 20152019 for northern and southern India in each season (Fig. 8) and month (Fig. 9) and show seasonal spatial distributions of these pollutants across India (Fig. S4). We analyze seasonal composites computed as averages for the spring or pre-monsoon period, March-April-May (MAM), the monsoon period, June-July-August (JJA), the autumn or post monsoon period, SeptemberOctober-November (SON) and winter, December-January-February (DJF). In all seasons, substantially higher concentrations are observed for $\mathrm{PM}_{10}$ and $\mathrm{PM}_{2.5}$, in northern India with concentrations of $\mathrm{NO}_{2}, \mathrm{SO}_{2}$ and $\mathrm{MDA} 8 \mathrm{O}_{3}$ only slightly more elevated in northern than southern India. The DJF average concentrations are highest for $\mathrm{PM}_{10}, \mathrm{PM}_{2.5}$ and $\mathrm{NO}_{2}$ in northern (southern) 
Northern India
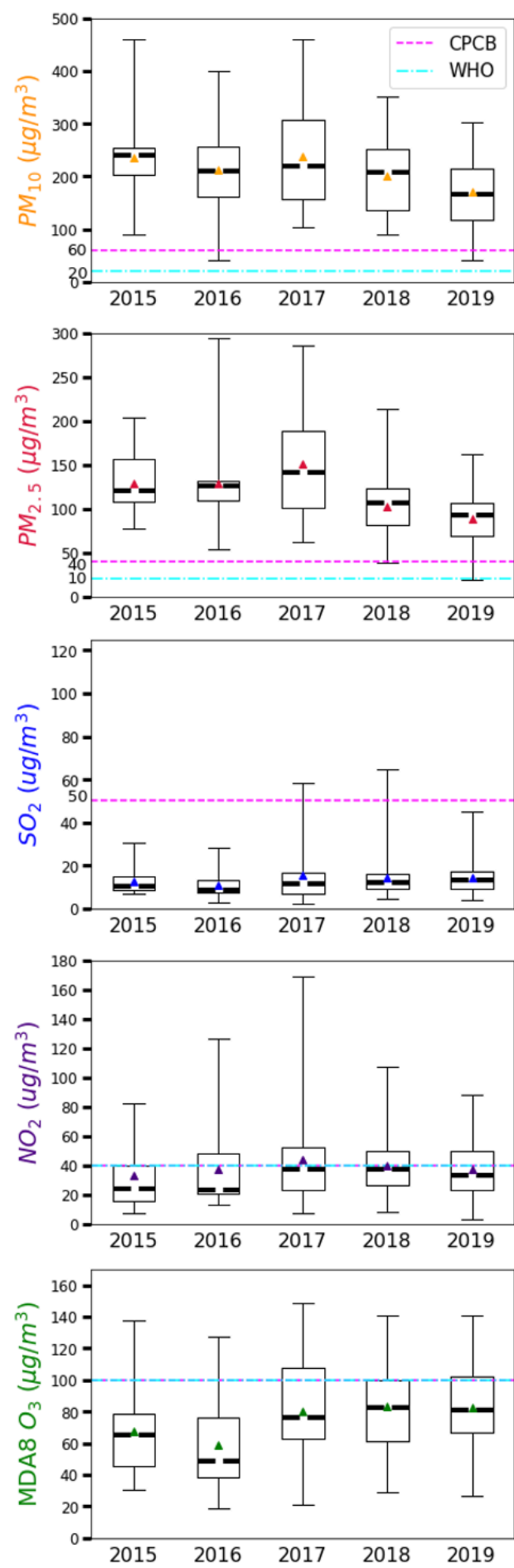

Southern India
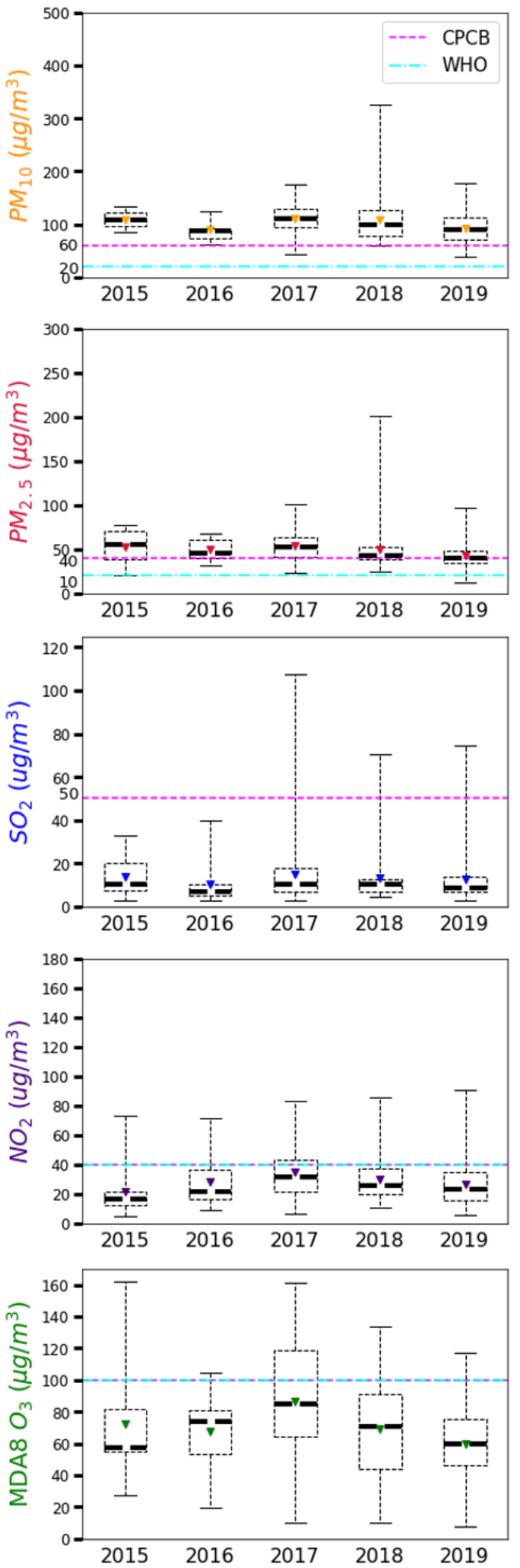

Fig. 6. Annual average concentrations $\left(\mu \mathrm{g} \mathrm{m}^{-3}\right)$ of $\mathrm{PM}_{10}, \mathrm{PM}_{2.5}, \mathrm{SO}_{2}, \mathrm{NO}_{2}$ and $\mathrm{MDA} 8 \mathrm{O}_{3}$ from all CAAQM continuous stations from 2015 through 2019, for northern and southern India (divided at $23.5^{\circ} \mathrm{N}$ and shown in left and right panels). Box edges indicate the interquartile range, whiskers indicate the maximum and minimum values, dashed lines inside the box are the medians and colored triangles indicate annual mean concentrations. CPCB and WHO ambient air quality standards are shown in magenta and blue dotted lines, respectively. Annual standards are provided for $\mathrm{PM}_{10}, \mathrm{PM}_{2.5}, \mathrm{NO}_{2}$ and $\mathrm{SO}_{2}$. (WHO does not provide an annual $\mathrm{SO}_{2}$ ambient air quality standard. It provides a 24-hour average standard of $40 \mathrm{\mu g} \mathrm{m}^{-3}$ ). For $\mathrm{O}_{3}$, maximum daily average 8-hour (MDA8) $\mathrm{O}_{3}$ standard is mentioned. (CPCB air quality standards apply to industrial, residential, rural and other areas. Ecologically sensitive areas have different standards and are not included). 

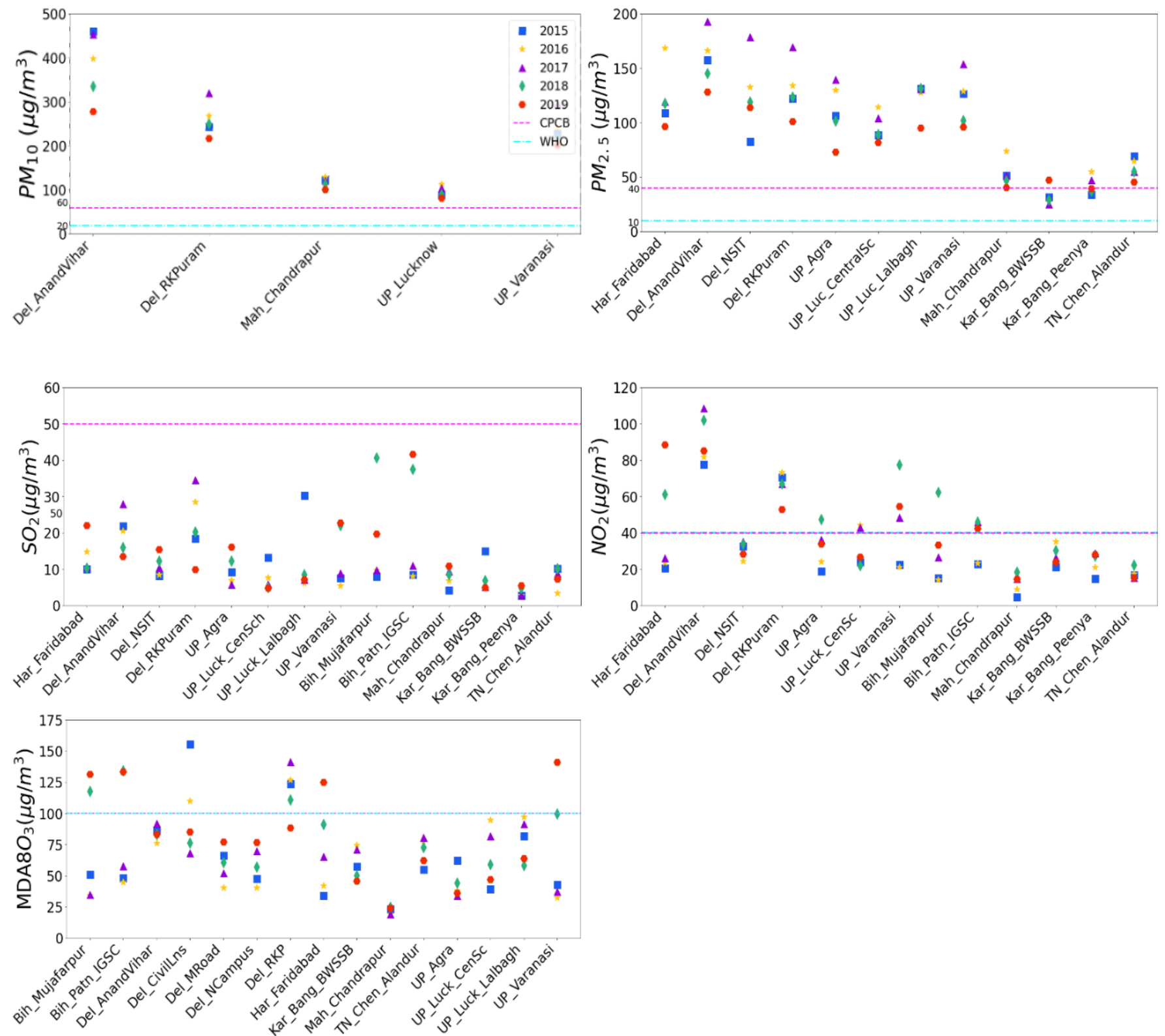

Fig. 7. Annual average concentrations $\left(\mu \mathrm{g} \mathrm{m} \mathrm{m}^{-3}\right.$ ) of $\mathrm{PM}_{10}, \mathrm{PM}_{2.5}, \mathrm{NO}_{2}$, and $\mathrm{SO}_{2}$, and $\mathrm{MDA} 8 \mathrm{O}_{3}$ concentrations from all CAAQM stations available in all years from 2015 through 2019 that meet our analysis criteria. Monitoring stations on the $x$-axis are arranged from north to south. New stations added after 2015 are not included and only stations operating in 2015 and thereafter that met our analysis criteria in all five years are included here. CPCB and WHO ambient air quality standards are shown in magenta and blue dotted lines, respectively. See Fig. 6 for details of standards. For the latitude and longitude of these stations, see Table S4.

India: $270 \pm 51(137 \pm 11) \mu \mathrm{g} \mathrm{m}^{-3}, 170 \pm 26(69 \pm 2) \mu \mathrm{g} \mathrm{m}^{-3}, 47 \pm 2(35 \pm 7) \mu \mathrm{g} \mathrm{m}^{-3}$, respectively. Seasonal average concentrations of $\mathrm{SO}_{2}$ peak in MAM in northern India $\left(15 \pm 3 \mu \mathrm{g} \mathrm{m}^{-3}\right)$ and in DJF in southern India $\left(16 \pm 4 \mu \mathrm{g} \mathrm{m}^{-3}\right)$, with highest concentrations in winter across the country. For DA8 $\mathrm{O}_{3}$, highest seasonal concentrations occur in MAM (DJF) in the north $71.8 \pm 28 \mu \mathrm{g} \mathrm{m}^{-3}$ and south $\left(84 \pm 8 \mu \mathrm{g} \mathrm{m}^{-3}\right)$.

Monthly variations in pollution are also a function of regional circulation patterns. The summer monsoon facilitates dilution of pollution via strong south-westerly winds from the Arabian Sea and wet scavenging of anthropogenic pollution (Zhu et al., 2012). Wet deposition removes $\mathrm{PM}_{10}$, $\mathrm{PM}_{2.5}$ and water soluble $\mathrm{SO}_{2}$ (Chin, 2012) leading to substantially lower ambient concentrations of these pollutants in JJA across India. Minimum concentrations of all pollutants occur in August. 

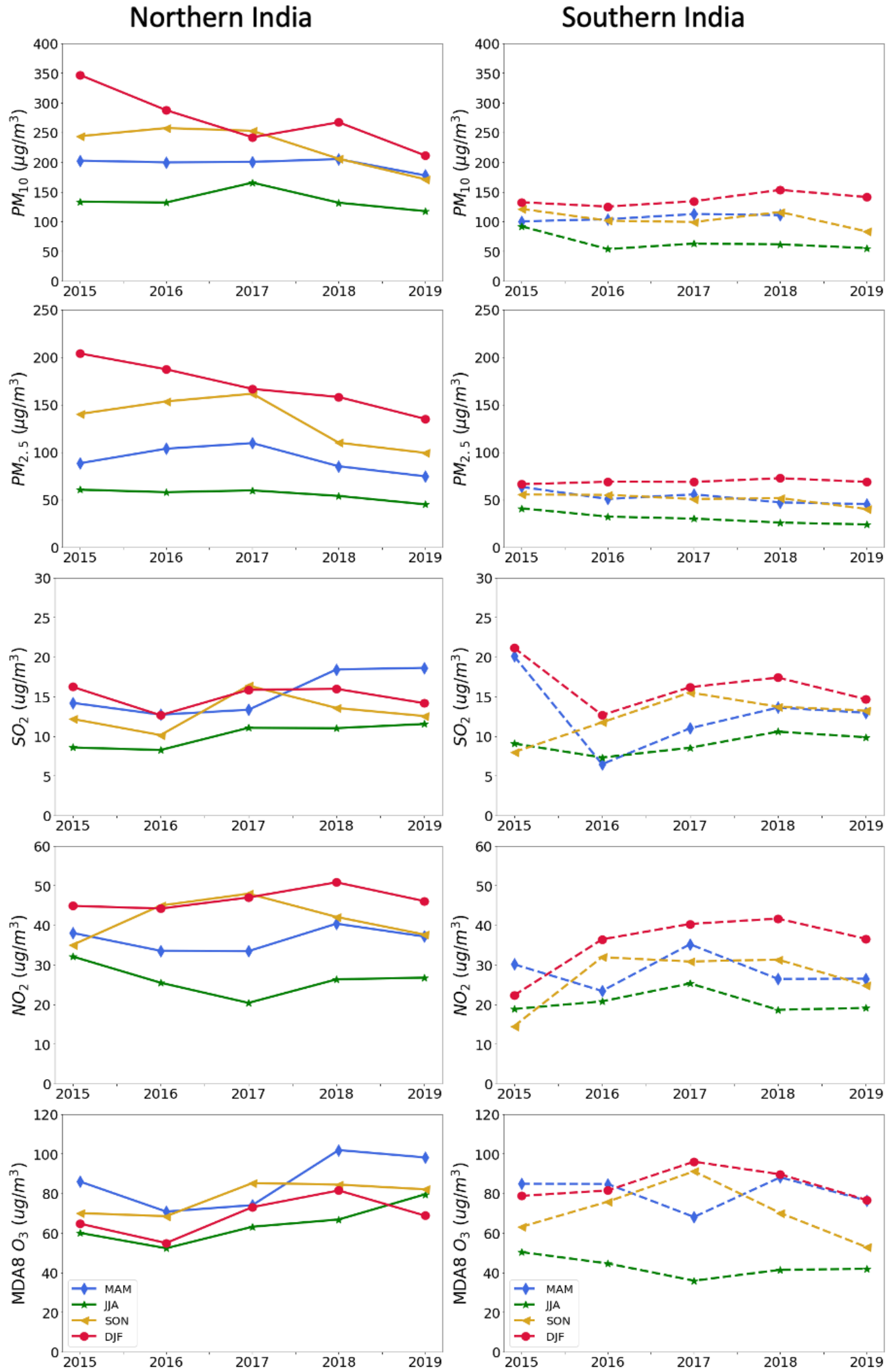

10

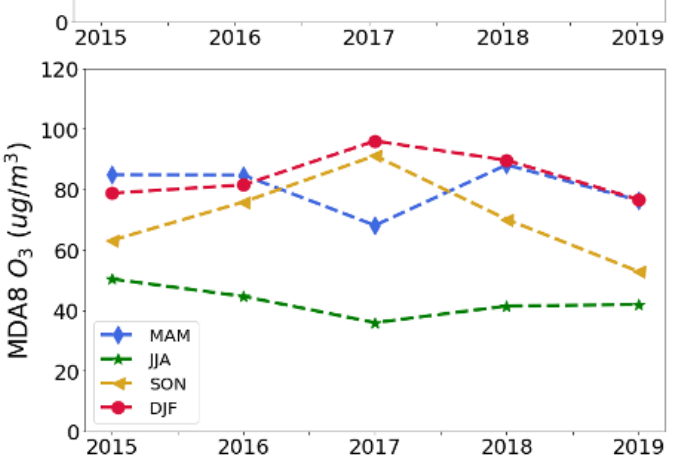

Fig. 8. Seasonal average concentrations for northern (solid lines) and southern India (dashed lines) (divided at $23.5^{\circ} \mathrm{N}$ latitude) from 2015-2019, inclusive, of $\mathrm{PM}_{10}, \mathrm{PM}_{2.5}, \mathrm{SO}_{2}, \mathrm{NO}_{2}$ and $\mathrm{MDA} 8 \mathrm{O}_{3}$ $\left(\mu \mathrm{g} \mathrm{m}^{-3}\right)$ from all CAAQM stations meeting analysis criteria. See Fig. 4 for station locations and annual average concentrations. 

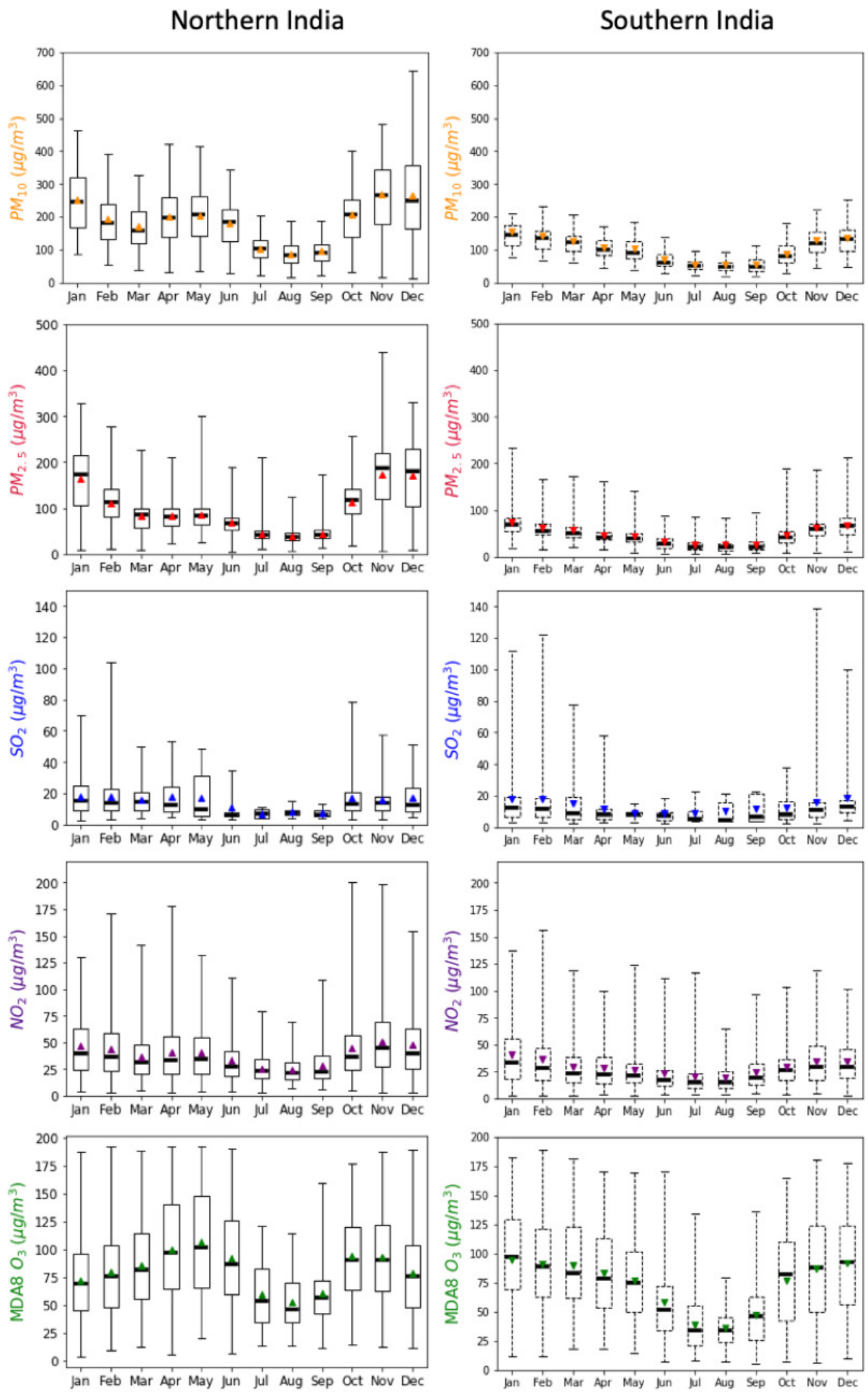

Fig. 9. Average monthly concentrations of $\mathrm{PM}_{10}, \mathrm{PM}_{2.5}, \mathrm{SO}_{2}, \mathrm{NO}_{2}$ and $\mathrm{MDA} 8 \mathrm{O}_{3}\left(\mu \mathrm{g} \mathrm{m}^{-3}\right)$ from northern and southern India from all CAAQM stations operational from 2015 to 2019 that meet our analysis criteria. Box edges indicate the interquartile range, whiskers indicate the maximum and minimum values, dashed lines inside the box are the medians and colored squares indicate annual mean concentrations. 
Outside the monsoon, weak regional circulation and large scale high pressure systems result in accumulation of pollutants near the surface which is most pronounced in winter. Highest monthly concentrations are seen in November-January, inclusive, for $\mathrm{PM}_{10}, \mathrm{PM}_{2.5}, \mathrm{SO}_{2}$ and $\mathrm{NO}_{2}$. For, $\mathrm{MDA}_{80}$, highest monthly concentrations are recorded in May (January) for northern (southern) India. Precursor emissions, surface temperature and solar insolation modulate a complex chemistry that drives the ozone cycle (Lu et al., 2018).

\subsection{Case studies of Delhi, Kolkata, Mumbai, Hyderabad and Chennai}

Delhi, Kolkata, Mumbai, Hyderabad and Chennai are the five cities in India in which the U.S. State Department Air-Now network real time monitoring stations record $\mathrm{PM}_{2.5}$ concentrations at the US embassy and consulates. In these five cities, we compare daily and monthly mean $\mathrm{PM}_{2.5}$ measurements from the Air-Now and CAAQM networks. Fig. 10 shows scatterplots between daily
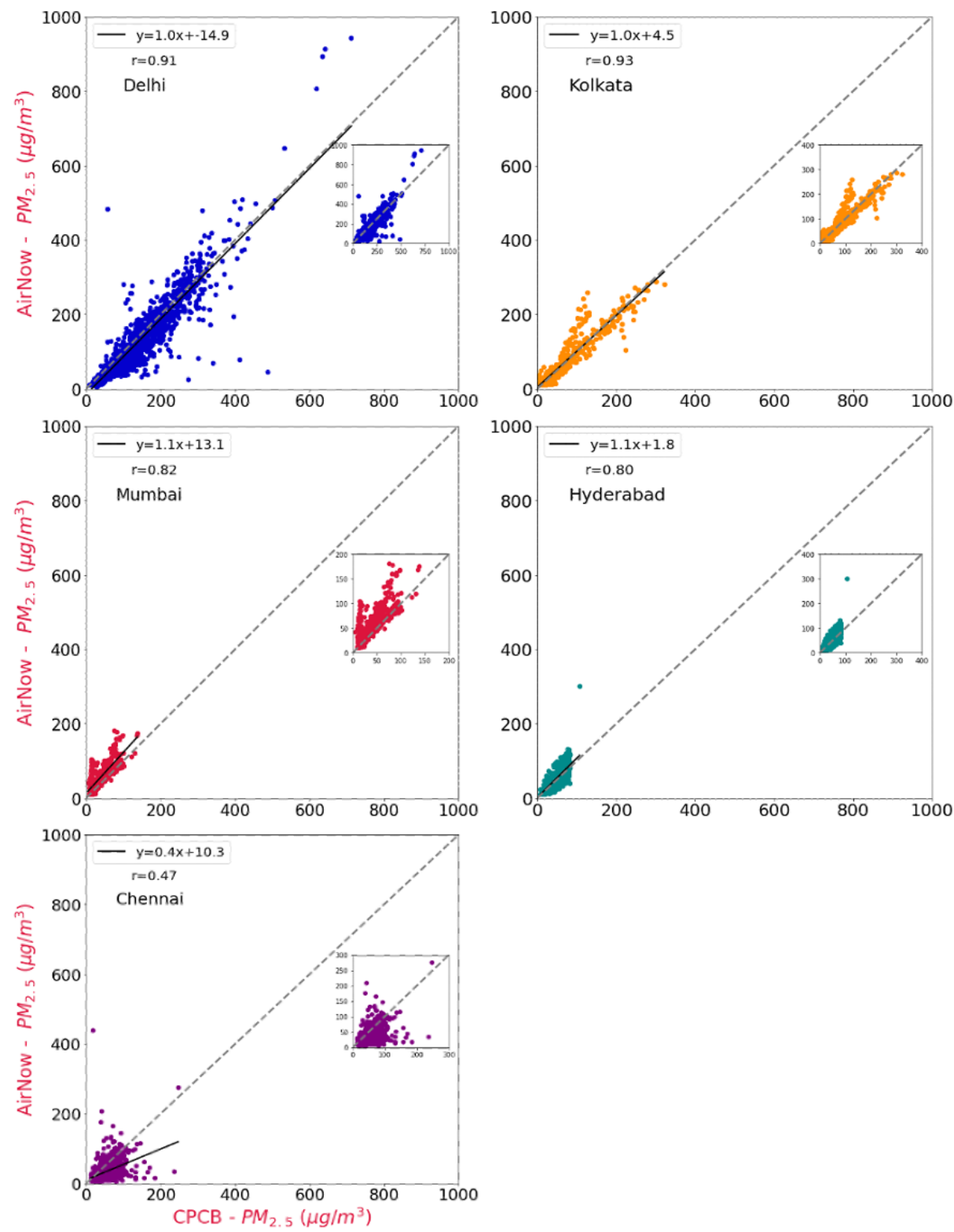

Fig. 10. Scatter plots of daily mean $\mathrm{PM}_{2.5}$ concentrations comparing Air-Now observations from the five cities in which they exist with all CPCB CAAQM monitors in those cities, between 20152019. For each plot the regression line (solid), regression equation and $r$ value for each correlation are shown for each city. The dashed grey line indicates 1:1 correspondence. The inset plots are scaled to the data range. 
mean $\mathrm{PM}_{2.5}$ from the Air-Now monitor located in each of the five cities with all CPCB CAAQM monitors in those cities for 2015-2019, inclusive. We find a good correlation between the daily average $\mathrm{PM}_{2.5}$ concentrations from the two networks at all the cities ( $\left.r>0.8\right)$, except Chennai $(r \sim 0.47)$ where CPCB concentrations are biased higher than the Air-Now concentrations. On highly polluted days in Delhi, the Air-Now monitors report higher $\mathrm{PM}_{2.5}$ concentrations than the CPCB monitors in part because Air-Now monitors are able to report hourly concentrations above $1000 \mu \mathrm{g} \mathrm{m}^{-3}$ while the CPCB monitors cannot.

We examine how concentrations of $\mathrm{PM}_{10}, \mathrm{PM}_{2.5}, \mathrm{SO}_{2}, \mathrm{NO}_{2}$ and $\mathrm{O}_{3}$ vary between cities in which Air-Now monitors exist from 2015-2019 (see Fig. 11). Fig. 11 compares the monthly average
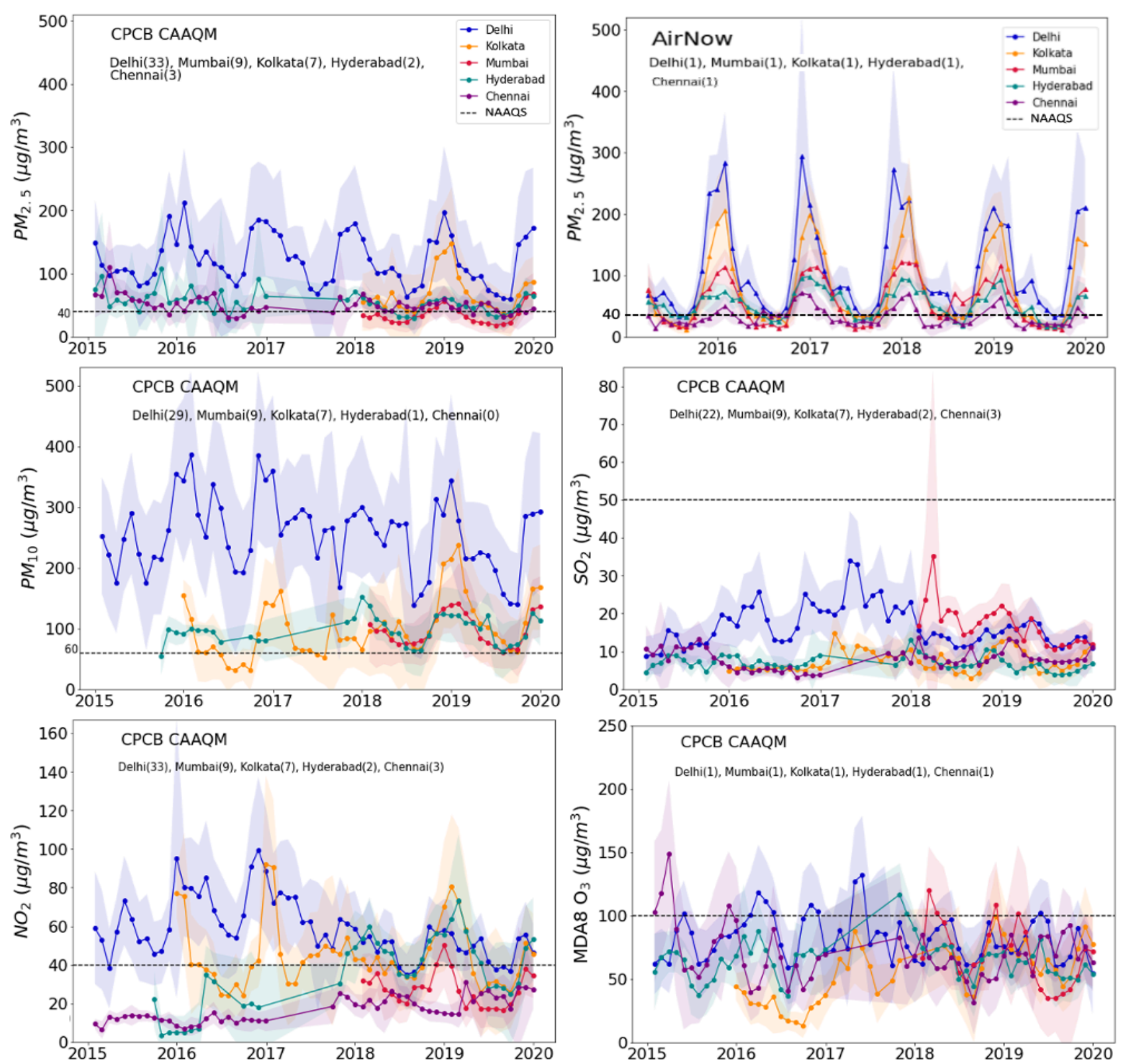

Fig. 11. Timeseries of monthly mean concentrations in Delhi, Kolkata, Mumbai, Hyderabad and Chennai (north to south order) of $\mathrm{PM}_{2.5}$ (CPCB CAAQM and Air-Now network) and $\mathrm{PM}_{10}, \mathrm{NO}_{2}, \mathrm{SO}_{2}$ and $\mathrm{MDA} 8 \mathrm{O}_{3}$ from all CAAQM stations in the five cities from 2015 to 2019 meeting our analysis criteria. The dots represent monthly means and the shaded region, in the same color as the dots, indicates values within one standard deviation of the mean for each city. Values following the station names indicate the number of monitoring stations included in the analysis of each city. Annual average residential area NAAQS for each pollutant are shown with a dashed black line $\left(\mathrm{PM}_{10}=60 \mu \mathrm{g} \mathrm{m}^{-3}, \mathrm{PM}_{2.5}=40 \mu \mathrm{g} \mathrm{m}^{-3} ; \mathrm{SO}_{2}=50 \mu \mathrm{g} \mathrm{m}^{-3} ; \mathrm{NO}_{2}=40 \mu \mathrm{g} \mathrm{m}^{-3} ; \mathrm{MDA} 8 \mathrm{O}_{3}=100 \mu \mathrm{g} \mathrm{m}{ }^{-3}\right.$ (not to be exceeded more than $2 \%$ of the year)). 
concentrations of $\mathrm{PM}_{2.5}$ between the two networks, examines the variation in concentrations over time for other species measured only by $\mathrm{CPCB}$, and compares observed concentrations with the annual NAAQS for residential areas. Annual average concentrations from the stations combined in each city that meet our criteria is shown in Fig. S5 and a timeseries for each pollutant at each station is shown in Fig. S6. From CAAQM and Air-Now networks, we find Delhi has the highest daily, monthly mean and annual average concentrations of $\mathrm{PM}_{10}$ and $\mathrm{PM}_{2.5}$, followed by Kolkata and Mumbai (Figs. 10, 11; Fig. S5).

For Delhi, between 2015 and 2019, annual average concentrations of $\mathrm{PM}_{2.5}$ from the CAAQM station closest to the U.S. embassy (RK Puram, Delhi) greatly exceeded the residential NAAQS for $\mathrm{PM}_{2.5}$ of $40 \mu \mathrm{g} \mathrm{m}^{-3}$ and ranged from 101 to $119 \mu \mathrm{g} \mathrm{m}^{-3}$ with the Air-Now station ranging from 95 to $124 \mu \mathrm{g} \mathrm{m}^{-3}$. Chennai has the lowest monthly and annual average concentrations of $\mathrm{PM}_{2.5}$. The US state department annual average $\mathrm{PM}_{2.5}$ values overall are consistent with the CAAQM stations

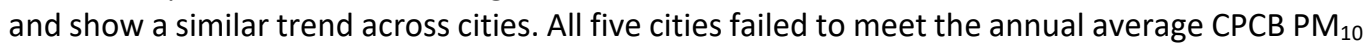
standard of $60 \mu \mathrm{g} \mathrm{m}^{-3}$ in all years.

Monthly and annual average $\mathrm{SO}_{2}$ concentrations are far below the annual standard of $50 \mu \mathrm{g} \mathrm{m}^{-3}$ at all locations throughout the year in these five cities with Delhi reporting the highest annual average concentrations among the five cities followed by Mumbai. Starting in 2018 both Delhi and Mumbai had $\mathrm{SO}_{2}$ concentrations lower than prior years.

Monthly average $\mathrm{NO}_{2}$ concentrations are highest in Delhi in all years and starting in 2017, decrease from a peak over $100 \mu \mathrm{g} \mathrm{m}^{-3}$ in 2017 to a peak of $52 \mu \mathrm{g} \mathrm{m}^{-3}$ in 2019. Kolkata and Hyderabad also have relatively high concentrations of $\mathrm{NO}_{2}$ with annual average concentrations exceeding the residential NAAQS of $40 \mu \mathrm{g} \mathrm{m}^{-3}$ starting in 2018.

Monthly $\mathrm{MDA}_{8} \mathrm{O}_{3}$ concentrations across all five cities are similar, particularly after 2018 and are generally falling below the residential 8-hour average NAAQS of $100 \mu \mathrm{g} \mathrm{m}^{3}$. Similar monthly tropospheric ozone concentrations in these cities, despite different levels of particulate matter, $\mathrm{NO}_{2}$ and meteorology, make it a topic for further investigation.

\section{DISCUSSION}

\subsection{Growing Dataset and Existing Gaps}

Prior to 2015 surface air quality monitoring data was available from only a few stations in India. Over the period we analyzed, 2015-2019, the number of monitoring stations across India increased dramatically. Our compilation and rigorous quality control of these data provide, for the first time, a comprehensive dataset of criteria pollutants that can be used to evaluate air pollutant concentrations simulated by atmospheric chemical transport models, satellite retrievals and reanalysis. Our dataset also provides a baseline for the NCAP. Previous studies have used ground observations from selected locations without transparently addressing existing data gaps and are not clear in their evaluation and quality assurance of surface observations. Here, we have carefully evaluated the archived data for completeness and accuracy, discarding values in excess of instrumental range, and requiring representative temporal coverage for each averaging period at each monitor. For example, for inclusion in our analysis a monitor measuring a species we analyze must report daily averages at least one hour per 12-hour daytime or night-time period, eight days for each monthly average, and one month per quarter and atleast two quarters for each annual average (see Tables S2(a), S2(b) and S3). However, spatial coverage remains spotty with monitoring stations predominantly located in large cities; smaller cities and rural locations lack coverage. Further expansion of the monitoring networks to facilitate an improved understanding of spatial distributions of pollutants across urban/rural India and to evaluate future trends in pollutant concentrations is needed. Very few stations provide valid observations continuously from 2015 onwards limiting our ability to analyze past trends in air quality. However, trend analyses starting in 2018 will be valuable and possible in the future.

\subsection{Differences in Air Quality Observations}

We compare monthly, seasonal and annual mean concentrations of air pollutants we analyze with other studies that have analyzed surface measurements of the same pollutants, cities and time periods across India (Table S5). We find that the range of concentrations of criteria pollutants 
reported in our analysis of $C P C B$ data are similar to the values presented in research studies using ground observations during the same period (Kota et al., 2018; Sreekanth et al., 2018; Guttikunda et al., 2019; Mahesh et al., 2019; Ravinder et al., 2019; Jain et al., 2020; Tyagi et al., 2020; Jat et al., 2021). However, as shown in Table S5, in case studies covering extreme events and studies in bigger cities and more polluted regions, like Delhi and the IGP, differences exist between the CPCB concentrations we calculate and those reported in the literature from surface monitoring stations, models and satellite data (Kota et al., 2018; Tyagi et al., 2019; Jat et al., 2021).

In Fig. 12, we compare the spatial patterns of annual average surface $\mathrm{PM}_{2.5}$ concentrations derived from satellite data with measurements from the CPCB continuous network. The surface satellite concentrations were obtained by combining data from Aerosol Optical Depth (AOD) from MODIS (Moderate Resolution Imaging Spectroradiometer), MISR (Multi-angle Imaging Spectroradiometer), MAIAC (Multi Angle Implementation of Satellite Correction) and SeaWiFS (Sea Viewing Wide Field of View Sensor) satellite products and using the GEOS-Chem model to obtain gridded surface $\mathrm{PM}_{2.5}$ concentrations at $0.05^{\circ} \times 0.05^{\circ}$ (Hammer et al., 2020). The product we use is V4.GL.03 available at https://sites.wustl.edu/acag/datasets/surface-pm2-5/\#V4.GL.03. Reasonable agreement is seen between the annual mean surface concentrations of $\mathrm{PM}_{2.5}$ derived from the satellite data and from the CPCB CAAQM observations from 2015-2019. Agreement is particularly good over the IGP and in central and southern India. However, along the western
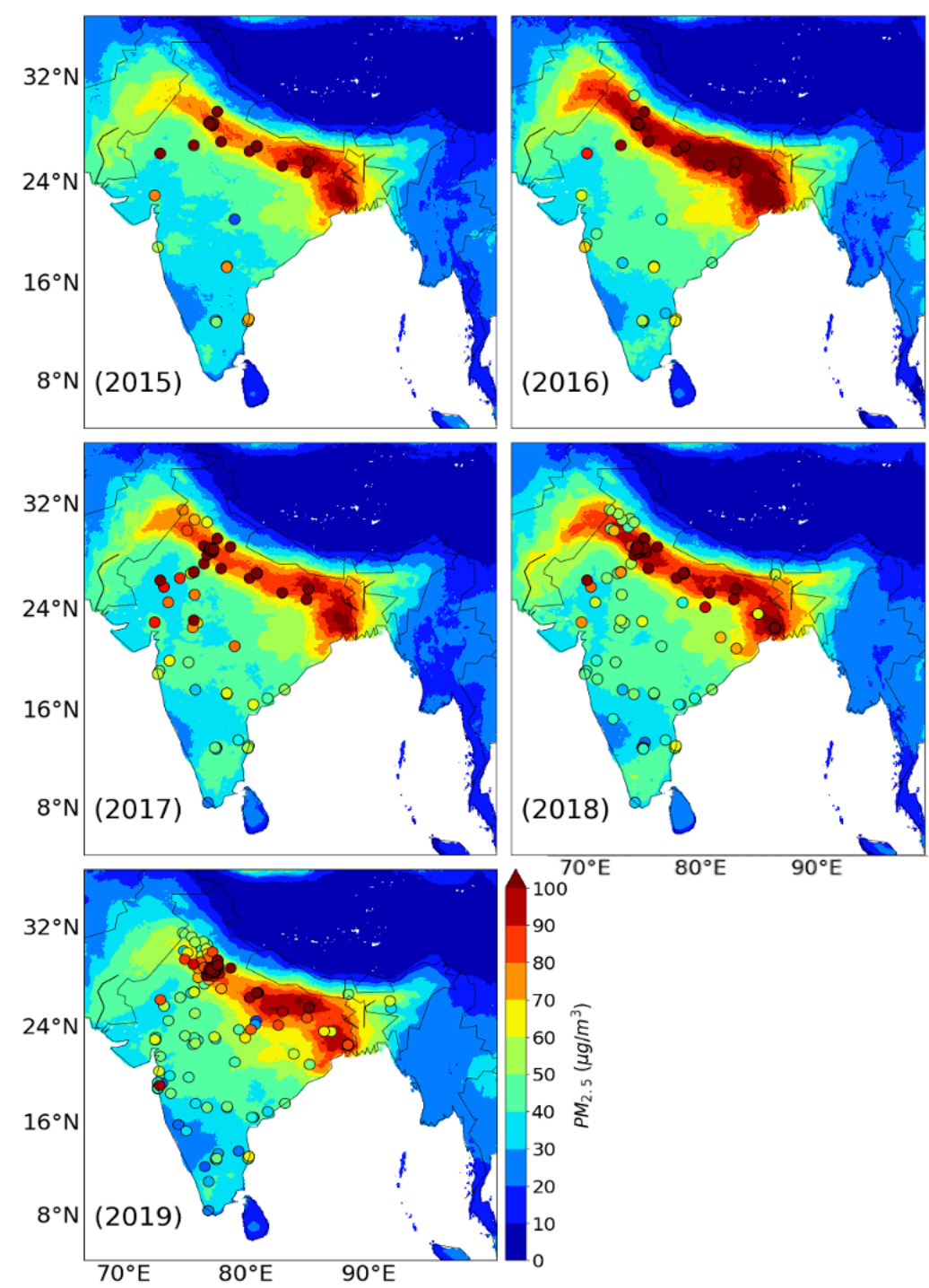

Fig. 12. Satellite derived annual surface $\mathrm{PM}_{2.5}$ concentration overlaid with CAAQM network surface measurements (circles), from 2015-2019. 
desert region (near Thar desert in Rajasthan), satellite concentrations of surface $\mathrm{PM}_{2.5}(\sim 40-$ $50 \mu \mathrm{g} \mathrm{m}^{-3}$ ) were substantially lower than concentrations obtained from the CPCB CAAQM monitors $\left(\sim 80-100 \mu \mathrm{g} \mathrm{m}^{-3}\right)$ for 2015-2017. In 2018 and 2019 the correspondence between the two datasets improved with most annual mean $\mathrm{PM}_{2.5}$ concentrations in the western desert region generally between $\sim 40$ and $60 \mu \mathrm{g} \mathrm{m}^{-3}$.

\section{CONCLUSIONS}

This study provides the first comprehensive analysis of all existing government monitoring data available for $\mathrm{PM}_{10}, \mathrm{PM}_{2.5}, \mathrm{SO}_{2}, \mathrm{NO}_{2}$ and $\mathrm{MDA} 8 \mathrm{O}_{3}$ using the continuous (CAAQM) and manual (NAMP) monitoring networks in India as well as the data from the US State Department Air-Now network, between 2015 and 2019 (2018 for NAMP). Our analysis shows that the Indian data record, in terms of number of monitoring stations, observations and quality of data, has improved significantly over this period. Despite the effort to augment surface monitoring infrastructure, gaps remain in spatial and temporal coverage and additional monitoring stations in small cities and rural areas are needed. Monitoring stations located in bigger cities (e.g., five Air-Now cities) have better data quality, from more widely distributed stations within the city, than is available for smaller cities. Pollution hotspots are occasionally found in smaller cities where monitoring stations are sparse. No stations have yet been placed in rural areas and are needed there in order to better characterize air quality and pollution sources across India (e.g., the effect of agricultural waste burning on air quality).

We find that fine particulate pollution dominates the pollution mix across India with virtually all sites in northern India (north of $23.5^{\circ} \mathrm{N}$ ) exceeding the annual average $\mathrm{PM}_{10}$ and $\mathrm{PM}_{2.5}$ national residential ambient air quality standards (NAAQS) by $150 \%$ and $100 \%$ respectively, and in southern India (south of $23.5^{\circ} \mathrm{N}$ ) exceeding the $\mathrm{PM}_{10}$ standard by $50 \%$ and $\mathrm{PM}_{2.5}$ standard by $40 \%$. Comparison of $\mathrm{PM}_{2.5}$ surface observations from the $\mathrm{CPCB}$ continuous monitoring network with surface satellite concentrations finds good agreement across India, particularly for 2017 and 2018. Prior to 2017 CAAQM concentrations were substantially higher than indicated by the satellite data over the western desert region. Annual average $\mathrm{SO}_{2}, \mathrm{NO}_{2}$ and $\mathrm{MDA} 8 \mathrm{O}_{3}$ generally meet the residential NAAQS across India. We find that northern India has ( 10\%-130\%) higher average concentrations of all pollutants than southern India, except for $\mathrm{SO}_{2}$ where the concentrations are similar. Although inter-annual variability exists, no significant trend of these pollutants was observed over the five-year period except for a small decrease over time in $\mathrm{PM}_{10}$ and $\mathrm{PM}_{2.5}$ in winter, which is more pronounced in the stations in northern and central India.

Our analysis of surface measurements is valuable for evaluating air pollutant concentrations simulated in atmospheric chemistry models. We found good agreement between the annual average CAAQM $\mathrm{PM}_{2.5}$ we analyzed and satellite derived surface $\mathrm{PM}_{2.5}$ from Hammer et al. (2020). Our data set can also be used to evaluate satellite retrievals of $\mathrm{NO}_{2}$ and $\mathrm{O}_{3}$ as well as seasonal variability in $\mathrm{PM}_{2.5}$ concentrations. Finally, India is targeting a reduction of $20-30 \%$ in particulate pollution under NCAP by 2024 relative to 2017 . Our analysis from 2015-2019 at different spatial and temporal scales of surface pollution provides a baseline to evaluate the future success of the programme as well as aids in the assessment of existing and future air pollution mitigation policies.

\section{ADDITIONAL INFORMATION}

\section{Data Access}

The raw data from the continuous CPCB monitors used in our analyses along with the code for data quality control and the calculation of various temporal averages is available at https://doi.org/10.34770/60j3-yp02

\section{ACKNOWLEDGEMENTS}

We thank Mi Zhou for early assistance in data processing and two anonymous reviewers for 
helpful suggestions to improve our manuscript. Funding for D.S. was provided by a Science, Technology and Environmental Policy fellowship at the Center for Policy Research on Energy and Environment at Princeton University.

\section{SUPPLEMENTARY MATERIAL}

Supplementary material for this article can be found in the online version at https://doi. org/10.4209/aaqr.210204

\section{REFERENCES}

Apte, J.S., Pant, P. (2019). Toward cleaner air for a billion Indians. PNAS 116, 10614-10616. https://doi.org/10.1073/pnas.1905458116

Avnery, S., Mauzerall, D.L., Fiore, A.M. (2013). Increasing global agricultural production by reducing ozone damages via methane emission controls and ozone-resistant cultivar selection. Global Change Biol. 19, 1285-1299. https://doi.org/10.1111/gcb.12118

Avnery, S., Mauzerall, D.L., Liu, J., Horowitz, L.W. (2011). Global crop yield reductions due to surface ozone exposure: 2. Year 2030 potential crop production losses and economic damage under two scenarios of $\mathrm{O}_{3}$ pollution. Atmos. Environ. 45, 2297-2309. https://doi.org/10.1016/ j.atmosenv.2011.01.002

Balakrishnan, K., Cohen, A., Smith, K.R. (2014). Addressing the burden of disease attributable to air pollution in India: The need to integrate across household and ambient air pollution exposures. Environ. Health Perspect. 122. https://doi.org/10.1289/ehp.1307822

Balakrishnan, K., Dey, S., Gupta, T., Dhaliwal, R.S., Brauer, M., Cohen, A.J., Stanaway, J.D., Beig, G., Joshi, T.K., Aggarwal, A.N., Sabde, Y., Sadhu, H., Frostad, J., Causey, K., Godwin, W., Shukla, D.K., Kumar, G.A., Varghese, C.M., Muraleedharan, P., Agrawal, A., et al. (2019). The impact of air pollution on deaths, disease burden, and life expectancy across the states of India: The Global Burden of Disease Study 2017. Lancet Planet. Heath 3, e26-e39. https://doi.org/10.101 6/S2542-5196(18)30261-4

Brauer, M., Guttikunda, S.K., Nishad, K.A., Dey, S., Tripathi, S.N., Weagle, C., Martin, R.V. (2019). Examination of monitoring approaches for ambient air pollution: A case study for India. Atmos. Environ. 216, 116940. https://doi.org/10.1016/j.atmosenv.2019.116940

Chen, Y., Wild, O., Conibear, L., Ran, L., He, J., Wang, L., Wang, Y. (2020). Local characteristics of and exposure to fine particulate matter $\left(\mathrm{PM}_{2.5}\right)$ in four Indian megacities. Atmos. Environ. 5, 100052. https://doi.org/10.1016/j.aeaoa.2019.100052

Chin, M. (2012). Dirtier air from a weaker monsoon. Nat. Geosci. 5, 449-450. https://doi.org/10.1 038/ngeo1513

Chowdhury, S., Dey, S. (2016). Cause-specific premature death from ambient $\mathrm{PM}_{2.5}$ exposure in India: Estimate adjusted for baseline mortality. Environ. Int. 91, 283-290. https://doi.org/10.1 016/j.envint.2016.03.004

Chowdhury, S., Dey, S., Di Girolamo, L., Smith, K.R., Pillarisetti, A., Lyapustin, A. (2019). Tracking ambient $\mathrm{PM}_{2.5}$ build-up in Delhi national capital region during the dry season over 15 years using a high-resolution (1 km) satellite aerosol dataset. Atmos. Environ. 204, 142-150. https://doi.org/10.1016/j.atmosenv.2019.02.029

Chowdhury, S., Pozzer, A., Dey, S., Klingmueller, K., Lelieveld, J. (2020). Changing risk factors that contribute to premature mortality from ambient air pollution between 2000 and 2015. Environ. Res. Lett. 15, 074010. https://doi.org/10.1088/1748 9326/ab8334

Cusworth, D.H., Mickley, L.J., Sulprizio, M.P., Liu, T., Marlier, M.E., DeFries, R.S., Guttikunda, S.K., Gupta, P. (2018). Quantifying the influence of agricultural fires in northwest India on urban air pollution in Delhi, India. Environ. Res. Lett. 13, 044018. https://doi.org/10.1088/17489326/aab303

Gao, M., Gao, J., Zhu, B., Kumar, R., Lu, X., Song, S., Zhang, Y., Jia, B., Wang, P., Beig, G., Hu, J., Ying, Q., Zhang, H., Sherman, P., McElroy, M.B. (2020). Ozone pollution over China and India: Seasonality and sources. Atmos. Chem. Phys. 20, 4399-4414. https://doi.org/10.5194/acp-204399-2020 
GDB Maps Working Group (2018). Burden of disease attributable to major air pollution sources in India. https://www.healtheffects.org/system/files/GBD-MAPS-SpecRep21-India-revised_0.pdf

Ghude, S.D., Jena, C., Chate, D.M., Beig, G., Pfister, G.G., Kumar, R., Ramanathan, V. (2014). Reductions in India's crop yield due to ozone. Geophys. Res. Lett. 41, 5685-5691. https://doi.org/10.1002/2014GL060930

Gurjar, B.R., Ravindra, K., Nagpure, A.S. (2016). Air pollution trends over Indian megacities and their local-to-global implications. Atmos. Environ. 142, 475-495. https://doi.org/10.1016/j.at mosenv.2016.06.030

Guttikunda, S.K., Gurjar, B.R. (2012). Role of meteorology in seasonality of air pollution in megacity Delhi, India. Environ. Monit. Assess. 184, 3199-3211. https://doi.org/10.1007/s10661-0112182-8

Guttikunda, S.K., Calori, G. (2013). A GIS based emissions inventory at $1 \mathrm{~km} \times 1 \mathrm{~km}$ spatial resolution for air pollution analysis in Delhi, India. Atmos. Environ. 67, 101-111. https://doi.org/10.1016/j.atmosenv.2012.10.040

Guttikunda, S.K., Nishadh, K.A., Jawahar, P. (2019). Air pollution knowledge assessments (APnA) for 20 Indian cities. Urban Clim. 27, 124-141. https://doi.org/10.1016/j.uclim.2018.11.005

Hama, S.M.L., Kumar, P., Harrison, R.M., Bloss, W.J., Khare, M., Mishra, S., Namdeo, A., Sokhi, R., Goodman, P., Sharma, C. (2020). Four-year assessment of ambient particulate matter and trace gases in the Delhi-NCR region of India. Sustainable Cities Soc. 54, 102003. https://doi.org/ 10.1016/j.scs.2019.102003

Hammer, M.S., van Donkelaar, A., Li, C., Lyapustin, A., Sayer, A.M., Hsu, N.C., Levy, R.C., Garay, M.J., Kalashnikova, O.V., Kahn, R.A., Brauer, M., Apte, J.S., Henze, D.K., Zhang, L., Zhang, Q., Ford, B., Pierce, J.R., Martin, R.V. (2020). Global estimates and long-term trends of fine particulate matter concentrations (1998-2018). Environ. Sci. Technol. 54, 7879-7890. https://doi.org/10. 1021/acs.est.0c01764

Jain, S., Sharma, S.K., Vijayan, N., Mandal, T.K. (2020). Seasonal characteristics of aerosols (PM 2.5 and $\mathrm{PM}_{10}$ ) and their source apportionment using PMF: A four year study over Delhi, India. Environ. Pollut. 262, 114337. https://doi.org/10.1016/j.envpol.2020.114337

Jat, R., Gurjar, B.R., Lowe, D. (2021). Regional pollution loading in winter months over India using high resolution WRF-Chem simulation. Atmos. Res. 249, 105326. https://doi.org/10.1016/j.at mosres.2020.105326

Kota, S.H., Guo, H., Myllyvirta, L., Hu, J., Sahu, S.K., Garaga, R., Ying, Q., Gao, A., Dahiya, S., Wang, Y., Zhang, H. (2018). Year-long simulation of gaseous and particulate air pollutants in India. Atmos. Environ. 180, 244-255. https://doi.org/10.1016/j.atmosenv.2018.03.003

Kulshrestha, M.J., Kulshrestha, U.C., Parashar, D.C., Vairamani, M. (2003). Estimation of $\mathrm{SO}_{4}$ contribution by dry deposition of $\mathrm{SO}_{2}$ onto the dust particles in India. Atmos. Environ. 37, 3057-3063. https://doi.org/10.1016/S1352-2310(03)00290-5

Lu, X., Zhang, L., Liu, X., Gao, M., Zhao, Y., Shao, J. (2018). Lower tropospheric ozone over India and its linkage to the South Asian monsoon. Atmos. Chem. Phys. 18, 3101-3118. https://doi.org/10.5194/acp-18-3101-2018

Mahesh, B., Rama, B.V., Spandana, B., Sarma, M.S.S.R.K.N., Niranjan, K., Sreekanth, V. (2019). Evaluation of MERRAero PM $_{2.5}$ over Indian cities. Adv. Space Res. 64, 328-334. https://doi.org/ 10.1016/j.asr.2019.04.026

Martin, R.V., Brauer, M., van Donkelaar, A., Shaddick, G., Narain, U., Dey, S. (2019). No one knows which city has the highest concentration of fine particulate matter. Atmos. Environ. 3, 100040. https://doi.org/10.1016/j.aeaoa.2019.100040

Ministry of Environment, Forests and Climate Change (MoEF) (2019). National Clean Air Program (NCAP). Government of India. http://moef.gov.in/wp-content/uploads/2019/05/NCAP_Repor t.pdf

National Ambient Air Quality Monitoring Program (NAMP) (2020). Data Year wise. https://cpcb.nic.in/namp-data/ (accessed 15 December 2020).

Navinya, C.D., Vinoj, V., Pandey, S.K. (2020). Evaluation of $\mathrm{PM}_{2.5}$ surface concentrations simulated by NASA's MERRA Version 2 aerosol reanalysis over India and its relation to the air quality index. Aerosol Air Qual. Res. 20, 1329-1339. https://doi.org/10.4209/aaqr.2019.12.0615

Pande, P., Dey, S., Chowdhury, S., Choudhary, P., Ghosh, S., Srivastava, P., Sengupta, B. (2018). Seasonal transition in $\mathrm{PM}_{10}$ exposure and associated all-cause mortality risks in India. Environ. 
Sci. Technol. 52, 8756-8763. https://doi.org/10.1021/acs.est.8b00318

Pandey, A., Brauer, M., Cropper, M.L., Balakrishnan, K., Mathur, P., Dey, S., Turkgulu, B., Kumar, G.A., Khare, M., Beig, G., Gupta, T., Krishnankutty, R.P., Causey, K., Cohen, A.J., Bhargava, S., Aggarwal, A.N., Agrawal, A., Awasthi, S., Bennitt, F., Bhagwat, S., et al. (2021). Health and economic impact of air pollution in the states of India: The Global Burden of Disease Study 2019. Lancet Planet. Heath 5, e25-e38. https://doi.org/10.1016/S2542-5196(20)30298-9

Pant, P., Lal, R.M., Guttikunda, S.K., Russell, A.G., Nagpure, A.S., Ramaswami, A., Peltier, R.E. (2019). Monitoring particulate matter in India: recent trends and future outlook. Air Qual. Atmos. Health 12, 45-58. https://doi.org/10.1007/s11869-018-0629-6

Ravindra, K., Singh, T., Mor, Sahil, Singh, V., Mandal, T.K., Bhatti, M.S., Gahlawat, S.K., Dhankhar, R., Mor, Suman, Beig, G. (2019). Real-time monitoring of air pollutants in seven cities of North India during crop residue burning and their relationship with meteorology and transboundary movement of air. Sci. Total Environ. 690, 717-729. https://doi.org/10.1016/j.scitotenv.2019.0 6.216

Sahu, S.K., Kota, S.H. (2017). Significance of $\mathrm{PM}_{2.5}$ air quality at the Indian capital. Aerosol Air Qual. Res. 17, 588-597. https://doi.org/10.4209/aaqr.2016.06.0262

Sharma, M., Dikshit, O. (2016). Comprehensive study on air pollution and green house gases (GHGs) in Delhi. A report submitted to Government of NCT Delhi and DPCC Delhi, 1-334. http://environment.delhigovt.nic.in/wps/wcm/connect/735190804acf830c8eec8f09c683c81 0/Final+Report09Jan2016.pdf?MOD=AJPERES\& $1 \mathrm{mod}=1109294014 \&$ CACHEID=735190804acf8 30c8eec8f09c683c810 (accessed 20 December 2020).

Sharma, S.K., Mandal, T.K., Sharma, A., Jain, S. (2018). Carbonaceous species of PM 2.5 in megacity Delhi, India during 2012-2016. Bull. Environ. Contam. Toxicol. 100, 6952.5701. https://doi.org/ 10.1007/s00128-018-2313-9

Silva, R.A., West, J.J., Lamarque, J.-F., Shindell, D.T., Collins, W.J., Faluvegi, G., Folberth, G.A., Horowitz, L.W., Nagashima, T., Naik, V., Rumbold, S.T., Sudo, K., Takemura, T., Bergmann, D., Cameron-Smith, P., Doherty, R.M., Josse, B., MacKenzie, I.A., Stevenson, D.S., Zeng, G. (2017). Future global mortality from changes in air pollution attributable to climate change. Nature Clim. Change 7, 647-651. https://doi.org/10.1038/nclimate3354

Sreekanth, V., Mahesh, B., Niranjan, K. (2018). Gradients in $\mathrm{PM}_{2.5}$ over India: Five city study. Urban Clim. 25, 992.5108. https://doi.org/10.1016/j.uclim.2018.06.001

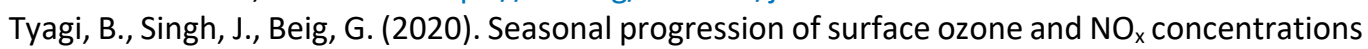
over three tropical stations in North-East India. Environ. Pollut. 258, 113662. https://doi.org/ 10.1016/j.envpol.2019.113662

Venkataraman, C., Brauer, M., Tibrewal, K., Sadavarte, P., Ma, Q., Cohen, A., Chaliyakunnel, S., Frostad, J., Klimont, Z., Martin, R.V., Millet, D.B., Philip, S., Walker, K., Wang, S. (2018). Source influence on emission pathways and ambient $\mathrm{PM}_{2.5}$ pollution over India (2015-2050). Atmos. Chem. Phys. 18, 8017-8039. https://doi.org/10.5194/acp-18-8017-2018

Wang, Y., Chen, Y. (2019). Significant climate impact of highly hygroscopic atmospheric aerosols in Delhi, India. Geophys. Res. Lett. 46, 55352.55545. https://doi.org/10.1029/2019GL082339

Yang, X., Jiang, L., Zhao, W., Xiong, Q., Zhao, W., Yan, X. (2018). Comparison of ground-based $\mathrm{PM}_{2.5}$ and $\mathrm{PM}_{10}$ concentrations in China, India, and the US. Int. J. Environ. Res. Public Health 15, 1382. https://doi.org/10.3390/ijerph15071382

Zhu, J., Liao, H., Li, J. (2012). Increases in aerosol concentrations over eastern China due to the decadal-scale weakening of the East Asian summer monsoon. Geophy. Res. Lett. 39, L09809. https://doi.org/10.1029/2012GL051428 